\title{
Az ortopédiai nagymútétek során alkalmazott terápiás szuggesztiók hatása a beteg gyógyulására
}

\author{
Szeverényi Csenge dr. ${ }^{1}$ - Csernátony Zoltán dr. ${ }^{1}$ - Balogh Ágnes ${ }^{3}$ \\ Simon Tünde dr. ${ }^{2}$ - Kekecs Zoltán $\mathbf{d r} .{ }^{4}$ - Varga Katalin $\mathbf{d r} .^{5}$ \\ Debreceni Egyetem, Általános Orvostudományi Kar, 'Ortopédiai Klinika, \\ ${ }^{2}$ Aneszteziológiai és Intenzív Terápiás Tanszék, Debrecen \\ ${ }^{3}$ Brüsszel, Belgium \\ ${ }^{4}$ Lund University, Department of Psychology, Lund, Svédország \\ ${ }^{5}$ Eötvös Loránd Tudományegyetem, Affektív Pszichológia Tanszék, Budapest
}

Bevezetés és célkitưzés: A csípő- és térdprotézisműtétek jelentős megterheléssel járnak a betegek számára. A mútétek körüli gyógyszeres fájdalomcsillapítás és szorongásoldás mellett a betegek gyógyulása az orvos-beteg kommunikáció során könnyen alkalmazható terápiás szuggesztiókkal is segíthető.

Módszer: Prospektív, randomizált, kontrollált tanulmányunkban csípő- és térdprotézisműtéten spinalis anesztéziában átesett betegeken vizsgáltuk a pozitív szuggesztiók hatását. A szuggesztiós csoport tagjai mútét előtti beszélgetés során, valamint mútét alatt hangfelvételről kapták a szuggesztiókat.

Eredmények: A kontrollcsoporthoz $(\mathrm{n}=50)$ képest a szuggesztiós csoportban $(\mathrm{n}=45)$ alacsonyabb volt a mútét alatti fájdalomcsillapítók és adjuváns szerek iránti összesített igény $(\mathrm{p}=0,037)$, jobb volt a betegek közérzetének átlagos változása a mútét utáni 2 . [1,31 $(0,57 ; 2,04) ; \mathrm{p}<0,001]$, illetve 4 . [0,97 $(0,23 ; 1,7) ; \mathrm{p}=0,011]$ napon, és kevesebb transzfúzió adására (OR: 2,37; $\mathrm{p}=0,004)$ volt szükség. Ugyanakkor nem mutatkozott különbség a mútét utáni gyógyszerek iránti igényben, a hospitalizáció időtartamában és a szövődmények gyakoriságában.

Következtetés: Eredményeink igazolják, hogy a terápiás szuggesztiók alkalmazása a mútét körüli időszakban kedvezően befolyásolja a gyógyulási folyamatot.

Orv Hetil. 2018; 159(48): 2011-2020.

Kulcsszavak: térdprotézis, csípőprotézis, szuggesztió, fájdalom, közérzet

\section{Effects of therapeutic suggestions on the recovery of patients undergoing major orthopaedic surgery}

Introduction and aim: Hip and knee replacement surgery is very demanding for patients. Medication consumption is further increased by perioperative anxiety. Besides pain killer and anxiolytic medications, patients' recovery can be enhanced by applying therapeutic suggestions, which are easily applicable during the patient-physician communication. Method: In our prospective, randomized, controlled study we examined the effects of positive suggestions on patients undergoing hip or knee arthroplasty in spinal anaesthesia. Members of the suggestion group received the therapeutic suggestions during a pre-surgery physician visit, and by listening to an audio recording during surgery.

Results: Compared to the control group $(n=50)$, in the suggestion group $(n=45)$ the need of medication (pain killer and adjuvant pain medication) during the surgery was lower $(\mathrm{p}=0.037)$, the mean change from baseline in the well-being of the patients was better on the 2 nd $[1.31(0.57 ; 2.04) ; \mathrm{p}<0.001]$ and 4 th $[0.97(0.23 ; 1.7) ; \mathrm{p}=0.011]$ postoperative day and less transfusion had to be administered (OR: 2.37; $\mathrm{p}=0.004$ ). However, there was no difference between the two groups in the postoperative need of medications, in the length of hospitalisation and in the frequency of complications.

Conslusion: Our results indicate that the administration of therapeutic suggestions in the perioperative period may be beneficial for orthopaedic surgery patients.

Keywords: knee replacement, hip replacement, suggestion, pain, well-being

Szeverényi Cs, Csernátony Z, Balogh Á, Simon T, Kekecs Z, Varga K. [Effects of therapeutic suggestions on the recovery of patients undergoing major orthopaedic surgery]. Orv Hetil. 2018; 159(48): 2011-2020.

(Beérkezett: 2018. június 7.; elfogadva: 2018. július 11.) 


\section{Rövidítések}

amp. $=$ ampulla; $\mathrm{BMI}=($ body mass index $)$ testtömegindex; CI $=($ confidence interval $)$ konfidenciaintervallum; $\mathrm{CRP}=\mathrm{C}$-reaktív protein; $\mathrm{EDA}=$ epidurális anesztézia; $\mathrm{Hgb}=$ hemoglobin; Htc $=$ hematokrit; iv. = intravénás; $\mathrm{K}=$ kontroll; NSAID = (non-steroid anti-inflammatory drug) nemszteroid gyulladáscsökkentő; OECD = $($ Organization for Economic Cooperation and Development) Gazdasági Együttmúködési és Fejlesztési Szervezet; $\mathrm{OR}=($ odds ratio $)$ esélyhányados; PICOS $=($ population, intervention, comparison, outcome, study design) populáció, intervenció, kontrollcsoport, kimenet, a vizsgálat típusa; po. = per os; $S=$ szuggesztiós; $\mathrm{SD}=$ standard deviáció; $\mathrm{SE}=$ standardizált egység; Sz. Cs. = Szeverényi Csenge; tabl. = tabletta; $\mathrm{We}=($ Westergren $)$ vörösvértest-süllyedés

Napjainkban az átlagéletkor és az idősebb generáció arányának növekedésével egyre több betegnél válik szükségessé a térd- vagy a csípőízület protetizálása. Magyarországon körülbelül 12-15 ezer csípő- és 5-6 ezer térdprotézis-beültetés történik évente [1]. A növekvő átlagéletkor, az egyre fiatalabb életkorban elvégzett mútétek és a revíziós mútétek számának emelkedése miatt az OECD tagországaiban 2030-ra a térdprotézismútétek száma a becslések szerint a négyszeresére fog nőni, és a csípőprotézis-mütétek száma is nagymértékben növekedni fog [1-3]. A nagyízületi protézismútétek komoly megterhelést jelentenek a beteg számára [4]. Mütét során gyakori az olyan fokú vérvesztés, amely transzfúzió adását teszi szükségessé. A posztoperatív időszakban fennálló fájdalom miatt a betegek napi szinten szorulnak fájdalomcsillapítók adására. A mútét körüli szorongás mértéke is jelentős, sőt kutatások igazolták azt is, hogy a szorongás mértéke korrelál a mútét utáni fájdalom mértékével [5] és a krónikus fájdalom kialakulásának valószínûségével is [6]. Tekintettel arra, hogy a protézismútétek kimenetelét, a hospitalizáció hosszát, a minél gyorsabb rehabilitációt, a betegek elégedettségét a fenti tényezők mindegyike jelentősen befolyásolja [7-12], nagyon fontos, hogy minden lehetséges eszközzel csökkentsük a betegek szorongását és fájdalmát a perioperatív időszakban. A klinikai gyakorlatban természetes, hogy rutinszerúen gyógyszereket alkalmazunk, a gyógyszerek mellékhatásai és az adagolás korlátozottsága miatt azonban egyre nagyobb az igény a nem farmakológiai alternatívák hatékonyságának tudományos feltárására (például betegoktatás) [13, 14]. Bizonyítékokon alapuló alternatívák például a relaxáció [15], a vezetett képzelet [16, 17], a kognitív viselkedésterápia [18] és a hipnózis [19].

Egy könnyen elsajátítható beavatkozási lehetőség a terápiás szuggesztiók alkalmazása. Terápiás szuggesztiók adhatók hipnózisban is [20-24], de számos kutatás igazolta hatékonyságukat hipnózisindukció nélkül is [2530]. A megfigyelések szerint kórházi körülmények között a betegek az őket érő fokozott stresszhatás következtében módosult tudatállapotba kerülnek, melynek során a szuggesztív hatások fokozottabban érvénye- sülnek náluk [31, 32]. Jakubovits és mtsai [28] hangfelvételról pozitív tartalmú szöveget játszottak le a betegeknek hasi mútétjük előtt és/vagy altatás közben, majd vizsgálták a szuggesztiók hatását a beteg állapotára. Eredményeik alapján a szuggesztiós csoport betegeinek a hangulata, közérzete, fájdalma és szorongása szignifikánsan kedvezőbbnek mutatkozott. Szilágyi és mtsai [29, 30] prospektív, randomizált, kontrollált vizsgálatokban tárták fel a pozitív szuggesztiók hatékonyságát intenzív terápiás osztályon több mint 48 órán át lélegeztetett betegeknél. Vizsgálataik során Varga és mtsai [33] eljárását alkalmazták. Eredményeik szerint a szuggesztiós csoport lélegeztetési ideje (szuggesztiós csoport: 85,2 $\pm 34,9$ óra; kontrollcsoport: $232,0 \pm 165,6$ óra) és az intenzív osztályon töltött napjaik száma (szuggesztiós csoport: 134,2 \pm 73,3 óra; kontrollcsoport: 314,2 \pm 178,4 óra) szignifikánsan csökkent a kontrollcsoporthoz képest. Kekecs és mtsai [25] randomizált, kontrollált vizsgálat során igazolták, hogy kataraktamütéten áteső betegek szorongása csökkent a mútét elött alkalmazott terápiás szuggesztiók hatására $(\mathrm{p}=0,004)$, és a betegek együttmúködőbbek is voltak a mútét során $(\mathrm{p}=0,01)$.

Összességében tehát a betegekkel való tudatosabb kommunikáció és a pozitív szuggesztiók beépítése a betegekkel való beszélgetésbe számos előnyt eredményezhet a beteg gyógyulásában, ami fontos a beteg és az orvos számára is, de az adott intézet költségvetésére is kihathat [34]. Vizsgálatunk célja az volt, hogy megállapítsuk, primer csípő- és térdprotézismütéten áteső betegeknél a mütét előtt és alatt alkalmazott terápiás szuggesztiók hatására kevesebb transzfúzióra van-e szükség, alacsonyabb-e a betegek mútét utáni fájdalomcsillapítószedése és szedatívumigénye, és ezzel együtt jobb-e a közérzetük azokhoz képest, akik nem részesülnek ilyen támogatásban. A vizsgálatunk elsődleges célkitűzésével, azaz a vérveszteséggel és a transzfúziós igénnyel kapcsolatos eredményeket korábban már publikáltuk [35].

\section{Módszer}

Kutatási kérdéseink a PICOS-modell alapján az 1. táblázatban láthatók [36]. A kizárási kritériumokat, melyeket a protokoll előre rögzített, a 2. táblázatban soroltuk fel. A vizsgálatot a Debreceni Egyetem Ortopédiai Klinikáján 2011. április és 2013. január között végeztük. A vizsgálati protokoll a kutatás során az elsődleges végpontot illetően módosult (a vérvesztés mennyisége helyett transzfúziós igényre) [35]. Egyebekben a protokollban nem történt semmilyen módosítás. A vizsgálat egy $\mathrm{PhD}$ tanulmány része, mely meghatározta a kutatás lebonyolítására rendelkezésre álló időt. Mivel a beválogatható vizsgálati személyek áramlása nem volt pontosan kiszámítható, a kutatás végpontját egy határidő eléréséhez kötöttük (2013. január). A vizsgálatban részt vevő betegek számának alakulása az 1 . ábrán látható.

A betegeket a mütétet megelőző napon a vizsgálatról szóban és írásban tájékoztattuk; a vizsgálatban való rész- 
1. táblázat |Vizsgálati kérdés a PICOS alapján

\begin{tabular}{|c|c|}
\hline Populáció & $\begin{array}{l}\text { Csípő-, térdprotézismütéten spinalis anesztéziá- } \\
\text { ban áteső felnőttek (kor } \geq 18)\end{array}$ \\
\hline Intervenció & $\begin{array}{l}\text { Szokásos kezelés + terápiás szuggesztiók (mütét } \\
\text { előtti beszélgetés + mútét alatti hanganyag) }\end{array}$ \\
\hline Kontrollcsoport & Szokásos kezelés \\
\hline Kimenet & $\begin{array}{l}\text { Beadott transzfúziók mennyisége; fádalomcsilla- } \\
\text { pítók iránti igény; adjuváns szerek iránti igény; } \\
\text { közérzet; hőemelkedés, láz előfordulása; We, } \\
\text { CRP; szövődmények gyakorisága; kórházban } \\
\text { töltött napok száma }\end{array}$ \\
\hline Vizsgálat típusa & Prospektív kontrollált klinikai vizsgálat \\
\hline
\end{tabular}

$\mathrm{CRP}=\mathrm{C}$-reaktív protein; PICOS $=$ (population, intervention, comparison, outcome, study design) populáció, intervenció, kontrollcsoport, kimenet, vizsgálat típusa; We = vörösvértest-süllyedés

\section{2. táblázat | Kizárási kritériumok}

\begin{tabular}{ll}
\hline Tényező & Oka \\
\hline Hallássérült & Nem hallja a szuggesztiókat \\
Jehova tanúi & Elutasítják a transzfúziót \\
Veleszületett vagy szerzett & Gyakoribb sebgyógyulási zavar \\
immundeficientia & \\
Diabetes mellitus & Gyakoribb sebgyógyulási zavar \\
Alkoholizmus & Gyakoribb sebgyógyulási zavar, \\
Fokozott vérzékenység & nagyobb vérzési kockázat \\
Gyakoribb sebgyógyulási zavar, & nagyobb vérzési kockázat \\
Mütéttechnikai szövődmény & $\begin{array}{l}\text { Gyakoribb szövődmények } \\
\text { (például csonttörés) }\end{array}$ \\
EDA, általános altatás & $\begin{array}{l}\text { fájdalom } \\
\text { Nem felel meg a beválasztási } \\
\text { kritériumnak }\end{array}$ \\
\hline
\end{tabular}

$\mathrm{BMI}=$ testtömegindex EDA = epidurális anesztézia

vétel önkéntes volt, a betegek minden esetben beleegyező nyilatkozatot írtak alá. A vizsgálatot a Debreceni Egyetem Regionális és Intézményi Kutatásetikai Bizottsága engedélyezte (3293-2010).

\section{Randomizálás}

A betegeket beleegyezésük után két csoportba randomizáltuk véletlen besorolással: 4-es blokkokat kialakítva rendeltük hozzá őket $1: 1$ arányban a kontroll-, illetve a szuggesztiós csoporthoz. A csoportba sorolást a statisztikus által a kutatásunkhoz készített Excel alkalmazás segítette. Egy adott 4-es blokkon belül az első betegeket érme feldobásával soroltuk csoportba; amikor egy blokkon belül az egy csoportba randomizált betegek száma elérte a maximumot (2), a standard eljárásnak megfelelően a többi beteg automatikusan a másik csoportba került. Stratifikált random csoportba sorolást alkalmaztunk, ez biztosította, hogy a mútét típusa (cementezett vagy cement nélküli csípő- vagy térdprotézis) és a sebész

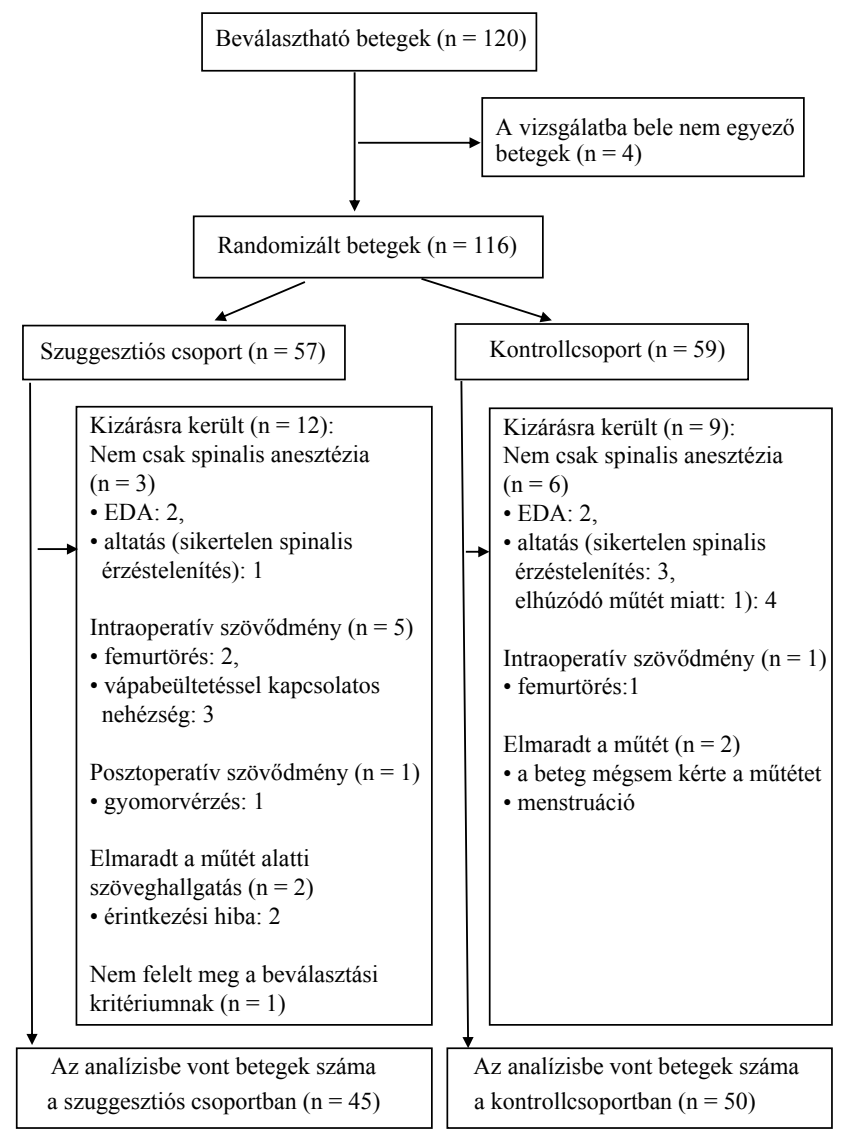

\begin{tabular}{l|l} 
1. ábra & $\begin{array}{l}\text { A betegek számának alakulása a vizsgálat során } \\
\text { EDA = epidurális anesztézia }\end{array}$
\end{tabular}

tapasztaltsága - melyek befolyásolhatják a kimeneti tényezóket - hasonló legyen a két csoportban. Azokat a sebészeket tekintettük tapasztaltnak, akik a szakvizsgájuk letételét követően már legalább 5 éve végeztek ízületi protetizálást.

\section{Csoportok}

Az intervenciós csoport betegei a mútét előtti napon olyan verbális tájékoztatást kaptak a várható mútéti eseményekről, mely tervezetten pozitív terápiás szuggesztiókat tartalmazott, majd a mútét alatt MP3-lejátszóról további terápiás szuggesztiókat hallgattak. A kontrollcsoport betegei a mútét elótt, alatt és után a szokásos felvilágosítást kapták meg kezelőorvosuktól és az aneszteziológustól. Tekintettel a beavatkozások természetére, a csoporttagság maszkolása nem volt megoldható, így a kezelőorvosok, a személyzet és a betegek is tudhatták, hogy melyik beteg melyik csoportba tartozik.

\section{Intervenciók}

A mútét előtti napon a szuggesztiós csoport betegei nemcsak az altatóorvostól és a sebésztől kapták meg a szokásos tájékoztatást, hanem részt vettek személyes be- 
szélgetésen is egy harmadik orvossal (az első szerzővel: Sz. Cs.), aki - bár ortopéd sebész - egyik betegnek sem volt a kezelőorvosa. Sz. Cs. a vizsgálat kapcsán elvégzett egy szuggesztiók alkalmazására felkészítő tanfolyamot. A beszélgetések során a betegek részletes tájékoztatást kaptak a rájuk váró eseményekről, de természetesen lehetőségük nyílt kérdéseket is feltenni és a félelmeikről, aggodalmaikról beszélni. A beszélgetések váza és a közben adandó szuggesztiók előre megtervezettek voltak, így minden beteg megkapta ugyanazokat a szuggesztiókat, vagy a tájékoztatás során, vagy a beteg által feltett kérdésekre adott válaszokba ágyazva. A beszélgetések átlagosan 20-40 percesek voltak. Az alkalmazott szuggesztiós technikákról ('igen' beállítódás, direkt szuggesztiók, átkeretezés, vezetés/követés, pozitív példa mutatása) bövebb információ korábbi közleményünkben [37], valamint az alábbi linken található: https://osf.io/7wvyd/.

A szuggesztiós csoport betegei a mütét során a mütét kezdetétól fejhallgatót kaptak, és MP3-lejátszóról hallgatták az elöre felvett hanganyagot. A 90 perces hanganyag során hét alkalommal hangzik el egy hétperces szöveg, melyeket lassú ritmusú, ambient stílusú zene köt össze. A szövegben elhangzó szuggesztiók célja a beteg megnyugtatása, relaxálása, a mútét alatti hangok átkeretezése (például a mütét során hallható fürészelés, kalapácsolás emlékeztesse a beteget egy ház felújítására, rendbetételére, amelyet - ahogy új ízületét - hamarosan birtokba vehet), a mútét utáni fájdalom csökkentése volt, és a beteg direkt szuggesztiókat is kapott a mütét körüli vérveszteség csökkentése érdekében. A teljes szöveg a következő linken érhető el: https://osf.io/7wvyd/. A betegek nem ismerték előre a hanganyag szövegét. Az összekötő zene stílusával jelentősen nem foglalkoztunk, hiszen kutatásunk célja a szuggesztiók hatékonyságának vizsgálata volt, melyekről azt gondoljuk, hogy olyan esetben is kifejtik hatásukat, amikor a zenét esetleg nem kedveli a beteg.

\section{Adatgyüjtés}

A kutatás menete a kimeneti adatok gyưjtésének időpontjaival a 2. ábrán látható. A számítógépes adatbázisból nyert információk alapján rögzítettük a betegek demográfiai adatait, a mütét típusát, az operatőr nevét, a mưtét időtartamát, a mütét alatti esetleges nehézségeket, szövődményeket.

A beteg kórházi tartózkodása alatt mértük a beadott transzfúziók számát, melyek eredményességét a vérképükkel kontrolláltuk.

A betegek mütéti jegyzőkönyvéből és lázlapjából kigyưjtöttük a mütét alatt és a mütét utáni időszakban alkalmazott fájdalomcsillapítók, szedatívumok mennyiségét. A mütét alatt a spinalis anesztézia kiegészítésére használt fájdalomcsillapító és szedatívum adását a leggyakrabban a mütéti területen kívüli régiókban, a tartós immobilizáció következtében kialakuló fájdalom és a beteg nyugtalansága indokolta. A mútétek során alkalma-

\section{Mütét elötti (0.) nap:}

Betegek beválasztása, beleegyező nyilatkozat aláírása, randomizáció Adatgyüjtés: BMI, We, CRP, Htc, Hgb, arcskála

Intervenció: beszélgetés

$\downarrow$

\section{Mütét alatt:}

Intervenció: hanganyag

\begin{tabular}{|l|} 
Mütét után, a mütét napján (1. nap): \\
Adatgyüjtés: We, CRP, Htc, Hgb \\
$\downarrow$
\end{tabular}

\section{2. posztoperatív nap:}

Adatgyüjtés: We, CRP, Htc, Hgb, arcskála

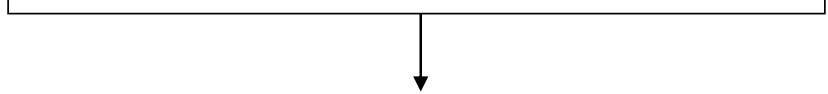

4. posztoperatív nap:

Adatgyüjtés: arcskála

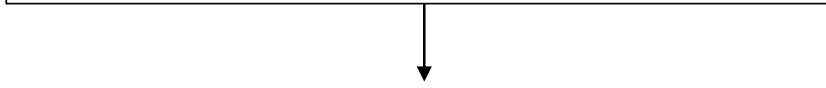

6. posztoperatív nap:

Adatgyüjtés: We, CRP, Htc, Hgb, arcskála, gyógyszerfogyasztás

\begin{tabular}{|c|c|}
\hline $\begin{array}{l}\text { A haz: } \\
\text { Adatg } \\
\text { korai }\end{array}$ & $\begin{array}{l}\text { tás napja: } \\
\text { : transzfúziók száma, láz, hőemelkedés előfordulása, } \\
\text { dmények, kórházban töltött napok száma }\end{array}$ \\
\hline 2. ábra & $\begin{array}{l}\text { A kutatás menete } \\
\mathrm{BMI}=\text { testtömegindex; } \mathrm{CRP}=\mathrm{C} \text {-reaktív protein; } \mathrm{Hgb}=\text { hemo- } \\
\text { globin; } \mathrm{Htc}=\text { hematokrit; } \mathrm{We}=\text { vörösvértest-süllyedés }\end{array}$ \\
\hline
\end{tabular}

zott gyógyszerelési rutin a következő linken érhető el: https://osf.io/7wvyd/. A mütét utáni időszakot két részre bontottuk: a mütét napjától a 2 . posztoperatív napig és a 3. posztoperatív naptól a 6. posztoperatív napig tartó periódusra. Ezt a fájdalomintenzitás változása és a szuggesztiós beavatkozástól való távolodás miatt tartottuk indokoltnak. A gyógyszereket fájdalomcsillapítókra (opioidszármazékok, NSAID-ok) és adjuváns szerekre osztottuk. Az adjuváns szerekhez soroltuk a szedatohipnotikumokat és az 1. és 2. generációs antipszichotikumokat is, melyeknek elsősorban nyugtató és altató hatásuk van, azonban fájdalomcsillapítást fokozó hatásuk is jelentős. A gyógyszerek hatáserőssége és dózisai alapján létrehoztunk egy standardizált egységbeosztást (3. és 4. táblázat), mellyel a gyógyszerfogyasztás a két csoport között összehasonlíthatóvá vált.

A betegek közérzetének mérésére McGrath [38] arcskálájának módosított változatát használtuk. Az arcskála egy vizuális értékelési skála, mely 9 stilizált arcot tartalmaz, amelyek különböző szintü komfortot vagy disz- 
3. táblázat $\mid$ Mútét alatt és után alkalmazott fájdalomcsillapítók standardizált egységei

\begin{tabular}{|c|c|c|c|c|}
\hline \multicolumn{5}{|c|}{ Fájdalomcsillapítók } \\
\hline & Opioid & SE & NSAID & SE \\
\hline \multirow[t]{2}{*}{ Mútét alatt } & $\begin{array}{l}\text { Nalbufin-hidro- } \\
\text { klorid, } 10 \mathrm{mg} \text { iv. }\end{array}$ & 2 & - & \\
\hline & Fentanil, $50 \mu \mathrm{g}$ iv. & 1 & - & \\
\hline \multirow[t]{3}{*}{ Mútét után } & $\begin{array}{l}\text { Nalbufin-hidro- } \\
\text { klorid, } 10 \mathrm{mg} \text { iv. }\end{array}$ & 2 & Diklofenák, 75 mg po. & 1 \\
\hline & $\begin{array}{l}\text { Tramadol, } \\
50 \mathrm{mg} \text { po. }\end{array}$ & 1 & $\begin{array}{l}\text { Metamizol-nátrium, iv. } \\
1 \mathrm{amp} / \mathrm{l} \text { tabl. }\end{array}$ & 0,5 \\
\hline & & & $\begin{array}{l}\text { Paracetamol-anilid, } \\
500 \mathrm{mg} \text { po. }\end{array}$ & 0,5 \\
\hline
\end{tabular}

NSAID = nemszteroid gyulladáscsökkentő; SE = standardizált egység

4. táblázat $\mid$ Mútét alatt és után alkalmazott adjuváns szerek standardizált egységei

\begin{tabular}{|c|c|c|c|c|}
\hline \multicolumn{5}{|c|}{ Adjuváns szerek } \\
\hline & Szedatohipnotikumok & SE & Antipszichotikumok & SE \\
\hline \multirow[t]{2}{*}{ Mútét alatt } & Midazolám, $1 \mathrm{mg}$ iv. & 0,5 & $\begin{array}{l}\text { Dehidrobenzperi- } \\
\text { dol, } 2,5 \text { mg iv. }\end{array}$ & 2 \\
\hline & Propofol, $10 \mathrm{mg}$ iv. & 1 & & \\
\hline \multirow[t]{6}{*}{ Mútét után } & $\begin{array}{l}\text { Midazolám, } 1 \mathrm{mg} \\
\text { iv. } / 7,5 \mathrm{mg} \text { po. }\end{array}$ & 0,5 & $\begin{array}{l}\text { Tiapridum, } \\
100 \mathrm{mg} \text { po. }\end{array}$ & 1,5 \\
\hline & $\begin{array}{l}\text { Brotizolám, } \\
0,25 \text { mg po. }\end{array}$ & 1 & $\begin{array}{l}\text { Haloperidol, } \\
5 \mathrm{mg} \text { iv. }\end{array}$ & 1,5 \\
\hline & Diazepám, 10 mg po. & 1 & & \\
\hline & $\begin{array}{l}\text { Alprazolám, } \\
0,25 \text { mg po. }\end{array}$ & 0,5 & & \\
\hline & $\begin{array}{l}\text { Klonazepám, } \\
0,5 \text { mg po. }\end{array}$ & 0,5 & & \\
\hline & $\begin{array}{l}\text { Meprobamát, } \\
200 \text { mg po. }\end{array}$ & 0,5 & & \\
\hline
\end{tabular}

SE = standardizált egység

komfortot kifejező arckifejezést mutatnak. Minden archoz 1 és 9 közötti számérték is tartozott, mely a közérzet milyenségére utal (az l-es szám jelölte a legrosszabb, a 9-es szám a legjobb közérzetet). A skálán a betegnek azt az arcot kellett megjelölnie, amelyik a leginkább tükrözte azt, hogy az adott pillanatban hogyan érezte magát. A méréseket mindkét csoport betegeinél Sz. Cs. végezte, lehetőség szerint a délelőtti órákban, melynek során a szerző a betegekkel az arcskála felvételére szorítkozva, célzott szuggesztiók nélkül beszélt. A szuggesztiós csoport betegeinél a közérzet mérésére mútét előtt a beszélgetést megelőzően került sor.

Rögzítésre került továbbá a hőemelkedés vagy láz előfordulása, a We- és CRP-értékek, valamint a mútét utáni időszakban fellépő bármilyen szövődmény (seroma, haematoma, punkció, reoperáció, trombózis, sebgyógyulási zavar, hyperaemia, elhúzódó hospitalizáció) előfordulása is. Dokumentáltuk a kórházban töltött napok számát is.

\section{Statisztikai módszerek}

A statisztikai számításokat R 3.3.2 és SAS 9.2 (ismételt mérési kevert modell) szoftverrel végeztük.

Csoportonként, időpontonként (mütét alatt, mütét utáni 1-2. és 3-6. napon) és gyógyszercsoportonként összesítettük a betegek gyógyszerfogyasztását és azon betegek arányát is, akiknél nem volt szükség az adott gyógyszercsoportból készítmény adására. A csoportok gyógyszerfogyasztását Wilcoxon-próbával hasonlítottuk össze.

A közérzetbecslő arcskálát és a We- és CRP-értékek alakulását ismételt mérési kevert modellel (repeated measures mixed model) vizsgáltuk, amelynek során a mútét előtti értéktől való változást modelleztük. A modell a következő magyarázó változókat tartalmazta: csoport, mútét előtti érték, mérési időpont (melyik posztoperatív nap?), illetve az időpont és a csoport interakciója.

Megnéztük a két csoportban azon betegek arányát, akiknek volt lázuk $\left(>38^{\circ} \mathrm{C}\right)$ vagy hőemelkedésük $\left(37^{\circ} \mathrm{C}-38^{\circ} \mathrm{C}\right)$, illetve azokét, akiknek volt szövődményük a kórházi tartózkodás alatt; a csoportok eloszlását Pearson-féle khi-négyzet-próbával hasonlítottuk össze.

A mútét napjától az elbocsátás napjáig kórházban töltött napok számát csoportonként összesítettük; a csoportok átlagát kétmintás t-próbával hasonlítottuk össze.

Az összes közölt statisztikai próbánál 5\%-os szignifikanciaszintet használtunk.

\section{Eredmények}

A vizsgálat során a beválasztott 116 betegből a kizárások után 45 beteg maradt a szuggesztiós és 50 beteg a kontrollcsoportban. Ahogy azt korábban már publikáltuk, a kiindulási demográfiai adatokban, a BMI-ben, a mütétek megoszlásban, a mútétek időtartamában és az operáló orvos tapasztalatában nem volt szignifikáns különbség a két csoport között [35] (5. táblázat). Szintén nem volt szignifikáns különbség a két csoport között a kiindulási laborértékekben és az arcskála értékében (5. táblázat). Ugyanebben a munkánkban beszámoltunk arról is, hogy a vizsgálat során a kontrollcsoporthoz képest a szuggesztiós csoportban szignifikánsan nagyobb volt azoknak az aránya, akiknek nem volt szükségük transzfúzióra (OR: $2,37 ; \mathrm{p}=0,004)$.

\section{Gyógyszerigény}

A 6. táblázat összesíti a mütét alatti gyógyszerek használatát. Minden gyógyszercsoportnál megfigyelhető, hogy a szuggesztiós csoport átlagos fogyasztása mindig alacsonyabb volt a kontrollcsoporténál, és hogy azon betegek aránya, akik egyáltalán nem kaptak az adott gyógyszercsoportból - gyógyszercsoporttól függően - 7-16\%kal nagyobb a szuggesztiós csoportban. Összesítve a mútét alatti gyógyszerigényt (fájdalomcsillapítók és adjuváns szerek) elmondható, hogy a szuggesztiós csoport 
5. táblázat | Demográfiai adatok, kiindulási labor és közérzeti értékek, a mútéti beavatkozás hossza

\begin{tabular}{|c|c|c|c|c|}
\hline & $\begin{array}{l}\text { Szuggesztiós } \\
\mathrm{n}=45\end{array}$ & $\begin{array}{l}\text { Kontroll } \\
\mathrm{n}=50\end{array}$ & $\begin{array}{l}\text { Összes } \\
\mathrm{n}=95\end{array}$ & p-érték ${ }^{\mathrm{a})}$ \\
\hline Átlagos életkor (SD), év & $67,1(7,50)$ & $64,6(9,98)$ & $65,8(8,94)$ & 0,173 \\
\hline Átlagos BMI (SD), $\mathrm{kg} / \mathrm{m}^{2}$ & $29,1(4,33)$ & $29,0(4,64)$ & $29,1(4,47)$ & 0,868 \\
\hline Férfi, n (\%) & $13(29)$ & $18(36)$ & $31(32,6)$ & \multirow{2}{*}{0,460} \\
\hline Nö, n (\%) & $32(71)$ & $32(64)$ & $64(67,4)$ & \\
\hline Az arcskála átlagos kiindulási értéke mútét előtt (SD) & $5,9(2,4)$ & $5,1(2,5)$ & $5,5(2,5)$ & 0,131 \\
\hline A We átlagos kiindulási értéke mútét előtt (SD), mm/h & $17,1(9,2)$ & $18,9(14,2)$ & $18,0(11,8)$ & 0,881 \\
\hline A CRP átlagos kiindulási értéke mútét előtt (SD), mg/l & $3,9(2,7)$ & $4,5(3,7)$ & $4,2(3,3)$ & 0,993 \\
\hline A mútét átlagos hossza (SD), perc & $110,0(28,9)$ & $109,5(27,26)$ & $109,7(27,9)$ & 0,931 \\
\hline
\end{tabular}

$\mathrm{BMI}=$ testtömegindex $; \mathrm{CRP}=\mathrm{C}$-reaktív protein $\mathrm{SD}=$ standard deviáció; $\mathrm{We}=$ vörösvértest-süllyedés

a)Statisztikai próbák: életkor, BMI, mútét hossza: kétmintás t-próba; arcskála, We, CRP: Wilcoxon-próba; nemek megoszlása: kétmintás próba arányok összehasonlítására

6. táblázat | Mútét alatti gyógyszerigény

\begin{tabular}{l|lll|llll}
\hline & $\begin{array}{l}\text { Szuggesztiós } \\
\mathrm{n}=45\end{array}$ & & $\begin{array}{l}\text { Kontroll } \\
\mathrm{n}=50\end{array}$ & & & \\
& $\begin{array}{l}\text { 0 egységet } \\
\text { kaptak }(\%)\end{array}$ & $\begin{array}{l}\text { Medián } \\
(\text { min.; max. })\end{array}$ & Átlag (SD) & $\begin{array}{l}\text { 0 egységet } \\
\text { kaptak }(\%)\end{array}$ & $\begin{array}{l}\text { Medián } \\
(\text { min.; max. })\end{array}$ & Átlag (SD) & p-érték $k^{\mathrm{a})}$ \\
\hline Fájdalomcsillapítók & $38(84,4 \%)$ & $0(0 ; 5)$ & $0,4(1,07)$ & $34(68 \%)$ & $0(0 ; 5)$ & $0,68(1,19)$ & 0,084 \\
\hline Adjuvánsok & $6(13,3 \%)$ & $3(0 ; 4,5)$ & $2,7(1,35)$ & $3(6 \%)$ & $3(0 ; 11,5)$ & $3,53(2,15)$ & 0,125 \\
\hline Összes & $6(13,3 \%)$ & $3(0 ; 9)$ & $3,1(1,85)$ & $3(6 \%)$ & $4(0 ; 15,5)$ & $4,21(2,83)$ & $0,037^{*}$ \\
\hline
\end{tabular}

${ }^{a}$ Wilcoxon-próba

$*<0,05$

Fájdalomcsillapítók: opioid, NSAID; adjuvánsok: szedatohipnotikumok, antipszichotikumok

gyógyszerigénye szignifikánsan kisebb volt a kontrollcsoportéhoz képest ( $\mathrm{p}=0,037)$.

A 3. ábrán látható, hogy a betegek többsége 3 vagy 4 egység gyógyszert kapott mind a két csoportban; de a kontrollcsoportban nagyobb azoknak az aránya, akik négynél több egységet kaptak, és kevesebb azoké, akik háromnál kevesebbet.

A mütét utáni gyógyszerigényt (fájdalomcsillapító és adjuváns szerek) a 7. táblázat összesíti. A szuggesztiós csoport átlagos gyógyszerfogyasztása minden időpontban, az összes gyógyszercsoportban konzisztensen alacsonyabb a kontrollcsoporténál, ám ez a különbség sosem szignifikáns vagy klinikailag releváns mértékű.

\section{Közérzetbecslö arcskála}

Az 8. táblázat időpontonként foglalja össze az átlagos arcskálaértékeket; specifikusan az átlagos változás a mútét előtti állapottól a 4 . ábrán is látható. A csoportonként mért eredmények minden időpontban kedvezőbbek (magasabbak) a szuggesztiós csoportban (így a mütét előtt is - de a különbség ekkor a legkisebb). Az átlagos változás a mútét előtti állapottól minden mütét utáni időpontban szintén nagyobb a szuggesztiós cso-
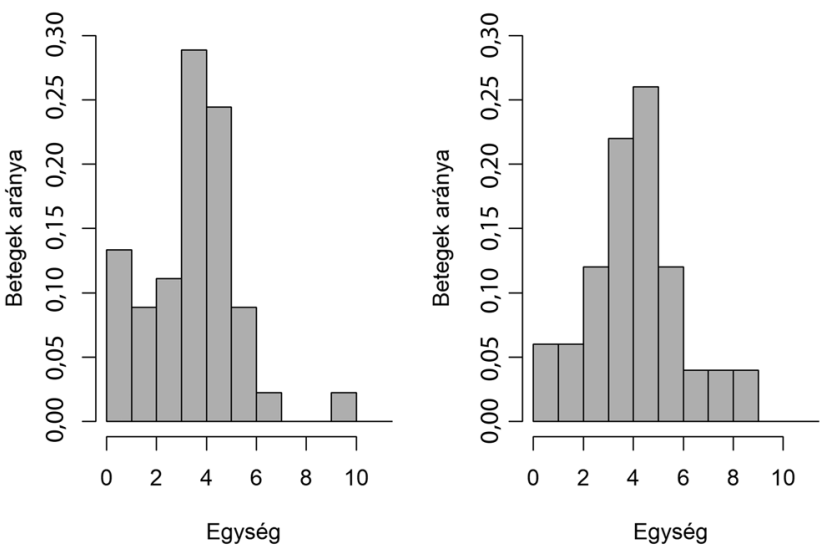

3. ábra $\quad$ A mútét alatt kapott gyógyszerek standard egységben mért eloszlása csoportonként

portban; ez a különbség a 2. napon 1,3 pont (p-érték $<0,001$ ) és a 4 . napon 1 pont (p-érték =0,011), ami ezen a 9 fokú skálán klinikailag is relevánsnak mondható. Specifikusan míg a mütét utáni 2. napon a kontrollcsoport közérzete kedvezőtlenebb lett, addig a szuggesztiós csoporté nem. 
7. táblázat | Mútét utáni gyógyszerigény

\begin{tabular}{|c|c|c|c|c|c|c|c|}
\hline & \multicolumn{3}{|l|}{$\begin{array}{l}\text { Szuggesztiós } \\
\mathrm{n}=45\end{array}$} & \multicolumn{3}{|l|}{\begin{tabular}{|l} 
Kontroll \\
$\mathrm{n}=50$
\end{tabular}} & \multirow[t]{2}{*}{ p-érték $k^{a)}$} \\
\hline & $\begin{array}{l}0 \text { egységet kaptak } \\
(\%)\end{array}$ & $\begin{array}{l}\text { Medián } \\
\text { (min.; max.) }\end{array}$ & Átlag (SD) & $\begin{array}{l}0 \text { egységet kaptak } \\
(\%)\end{array}$ & $\begin{array}{l}\text { Medián } \\
\text { (min.; max.) }\end{array}$ & Átlag (SD) & \\
\hline $\begin{array}{l}\text { Fájdalomcsillapítók } \\
1-2 \text {. nap }\end{array}$ & $0(0 \%)$ & $8(4 ; 17)$ & $8,58(2,86)$ & $0(0 \%)$ & $9(3 ; 17)$ & $8,84(2,50)$ & 0,598 \\
\hline $\begin{array}{l}\text { Fájdalomcsillapítók } \\
\text { 3-6. nap }\end{array}$ & $3(6,7 \%)$ & $6(0 ; 13)$ & $5,56(2,88)$ & $1(2 \%)$ & $6(0 ; 16,5)$ & $6,08(2,57)$ & 0,491 \\
\hline $\begin{array}{l}\text { Fájdalomcsillapítók } \\
\text { 1-6. nap }\end{array}$ & $0(0 \%)$ & $14(5,5 ; 26,5)$ & $14,14(4,72)$ & $0(0 \%)$ & $15(4 ; 26,5)$ & $14,92(3,88)$ & 0,481 \\
\hline Adjuvánsok 1-2. nap & $22(48,9 \%)$ & $1(0 ; 9)$ & $1,17(1,79)$ & $23(46 \%)$ & $1(0 ; 15)$ & $1,44(2,91)$ & 0,968 \\
\hline Adjuvánsok 3-6. nap & $7(15,6 \%)$ & $3(0 ; 5,5)$ & $2,81(1,62)$ & $7(14 \%)$ & $3(0 ; 15,5)$ & $2,94(2,56)$ & 0,659 \\
\hline Adjuvánsok 1-6. nap & $4(8,9 \%)$ & $4(0 ; 14,5)$ & $3,98(2,69)$ & $2(4 \%)$ & $3,25(0 ; 30,5)$ & $4,38(4,54)$ & 0,828 \\
\hline Összes 1-2. nap & $0(0 \%)$ & $9,5(4 ; 22,5)$ & $9,74(3,70)$ & $0(0 \%)$ & $9,75(4 ; 23)$ & $10,28(3,26)$ & 0,394 \\
\hline Összes 3-6. nap & $1(2,2 \%)$ & $9(0 ; 17,5)$ & $8,37(3,73)$ & $1(2 \%)$ & $8,5(0 ; 19,5)$ & $9,02(3,84)$ & 0,654 \\
\hline Összes 1-6. nap & $0(0 \%)$ & $18,5(6,5 ; 32)$ & $18,1(6,02)$ & $0(0 \%)$ & $19(12,5 ; 42)$ & $19,30(5,29)$ & 0,526 \\
\hline
\end{tabular}

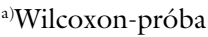

Fájdalomcsillapítók: opioid, NSAID; adjuvánsok: szedatohipnotikumok, antipszichotikumok

8. táblázat |Arcskála: átlagos értékek időpontonként

\begin{tabular}{|c|c|c|c|}
\hline & $\begin{array}{l}\text { Szuggesz- } \\
\text { tiós }\end{array}$ & Kontroll & $\begin{array}{l}\text { A mútét előtti } \\
\text { állapottól való } \\
\text { átlagos változás } \\
\text { csoportok közötti } \\
\text { különbsége } \\
\text { 95\% CI, p-érték }\end{array}$ \\
\hline \multicolumn{4}{|l|}{ Mütét elött } \\
\hline Betegek száma & 45 & 50 & \\
\hline Átlag (SD) & $5,9(2,43)$ & $5,1(2,49)$ & \\
\hline \multicolumn{4}{|l|}{ Mütét utáni 2. nap } \\
\hline Betegek száma & 45 & 50 & \\
\hline Átlagos érték (SD) & $6(2,2)$ & $4,6(2,14)$ & \\
\hline $\begin{array}{l}\text { Átlagos változás } \\
\text { a mútét elootti } \\
\text { állapottóla) }^{a}, 95 \% \mathrm{CI}\end{array}$ & $\begin{array}{l}0,43(-0,1 ; \\
0,96)\end{array}$ & $\begin{array}{l}-0,88 \\
(-1,38 \\
-0,37)\end{array}$ & $\begin{array}{l}1,31(0,57 ; 2,04) \\
<0,001 *\end{array}$ \\
\hline \multicolumn{4}{|l|}{ Mütét utáni 4. nap } \\
\hline Betegek száma & 45 & 49 & \\
\hline Átlagos érték (SD) & $7,1(1,6)$ & $5,9(1,92)$ & \\
\hline 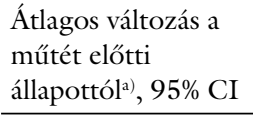 & $\begin{array}{l}1,45(0,92 \\
1,99)\end{array}$ & $\begin{array}{l}0,49 \\
(-0,02 ; 1)\end{array}$ & $\begin{array}{l}0,97(0,23 ; 1,7) \\
0,011^{*}\end{array}$ \\
\hline \multicolumn{4}{|l|}{ Mütét utáni 6. nap } \\
\hline Betegek száma & 45 & 43 & \\
\hline Átlagos érték (SD) & $7,5(1,49)$ & $6,7(1,78)$ & \\
\hline $\begin{array}{l}\text { Átlagos változás } \\
\text { a mütét előtti } \\
\text { állapottóla) }^{a}, 95 \% \mathrm{CI}\end{array}$ & $\begin{array}{l}1,92(1,39 \\
2,45)\end{array}$ & $\begin{array}{l}1,19(0,65 \\
1,72)\end{array}$ & $\begin{array}{l}0,73(0,02 ; 1,49) \\
0,057\end{array}$ \\
\hline
\end{tabular}

\section{We, CRP, láz, szövődmények, kórházi napok}

Az átlagos We- és CRP-értékek változása (melyet online mellékletként a következő oldalra feltöltöttünk: https:// osf.io/7wvyd/) a mútét utáni 2. és 6 . napon nem különbözik szignifikánsan a két csoportban, sem a We-re $(\mathrm{p}=$ $0,71)$, sem a CRP-re $(\mathrm{p}=0,73)$ vonatkozóan.

A szuggesztiós csoportban azoknak az aránya, akiknek volt lázuk vagy hőemelkedésük, $58 \%$ volt, míg ugyanez az érték a kontrollcsoportban $52 \%$ (p-érték = 0,72). A szövődmények előfordulási gyakorisága $11 \%$ a szuggesztiós, $18 \%$ a kontrollcsoportban $(\mathrm{p}=0,51)$. Az átlagosan kórházban töltött napok száma 8,7 nap mind a két csoportban (szuggesztiós csoport: $\mathrm{SD}=1,94$; kontrollcsoport: $S D=3 ;$ p-érték $=0,89$ ).

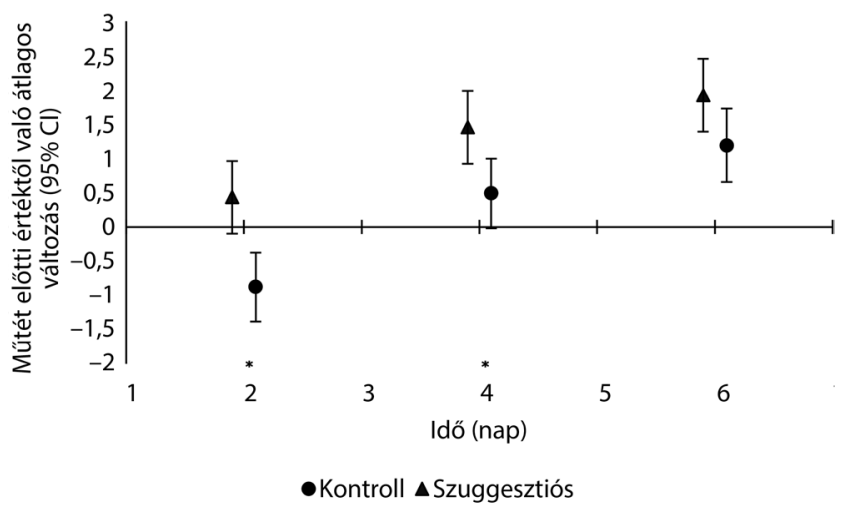

\begin{tabular}{l|l} 
4. ábra & A közérzet átlagos változása a mútét előtti állapothoz képest
\end{tabular} $\mathrm{CI}=$ konfidenciaintervallum *A két csoport közti különbség szignifikáns 


\section{Megbeszélés}

Mivel a csípő- és térdprotézis-beültetések száma a jövőben várhatóan jelentősen emelkedni fog, mind a gazdasági, mind a személyes szempontokat szem elött tartva érdekünk, hogy a betegek ellátását és gyógyulását minden lehetséges eszközzel segítsük. Ennek egyik módja annak kiaknázása, hogy a betegek a kórházi környezetben spontán módosult tudatállapotba kerülhetnek, és így fokozottan érzékenyek lesznek az őket érő pozitív és negatív szuggesztiókra különösebb indukció vagy szuggesztibilitást fokozó eljárás nélkül. Mindezeket figyelembe véve az orvosi gyakorlatban nagyon fontos a negatív szuggesztiók tudatos elkerülése és a transzállapot pozitív irányba történő vezetése a betegnek adott terápiás szuggesztiókkal [31, 33, 38-42].

Vizsgálatunk során arra kerestünk választ, hogy ortopédiai nagymütéteknél, a műtét előtt és a műtét alatt alkalmazott szuggesztiók hogyan segítik a beteg gyógyulását. Az eredmények alapján a szuggesztiók hatására a transzfúziós igény [35], valamint a mütét alatt adott gyógyszerek mennyisége csökkent, ugyanakkor a mútét utáni fájdalomcsillapítók és adjuváns szerek iránti igényben nem találtunk különbséget. Intervenciónk hatására a betegek közérzete is szignifikánsan kedvezőbben változott a mütét utáni 2. és 4. napra. A szövődményeket illetően, a láz és a hőemelkedés gyakoriságában, a We- és CRP-értékekben és a kórházban töltött napok számát tekintve nem találtunk különbséget a két csoport között.

A szuggesztiós csoport átlagos gyógyszerigénye minden mérési időpontban és minden gyógyszercsoportban konzisztensen alacsonyabb volt a kontrollcsoporténál. Az átlagok közti különbség a mütét utáni gyógyszerigények tekintetében klinikailag nem releváns, viszont a mütét alatti gyógyszerigény eloszlásai közti (nemparaméteres) különbség nemcsak statisztikailag, hanem klinikailag is releváns. Azoknak a betegeknek az aránya, akiknek 4 egységnél több gyógyszerre volt szükségük, $11 \%$-kal nagyobb a kontrollcsoportban; ugyanakkor azoknak a betegeknek az aránya, akiknek egyáltalán nem volt szükségük gyógyszerre, 7\%-kal nagyobb a szuggesztiós csoportban. Ez utóbbi azért is fontos, mert ez független attól, hogy melyik gyógyszerhez mekkora standard egységet rendeltünk. Ugyanakkor eredményeink alapján az is látható, hogy - elsősorban a mútét utáni időszakban - az alkalmazott szuggesztiók hatására a fájdalomcsillapítók és adjuváns szerek iránti igény nem mutatott szignifikáns csökkenést. Ez az eredmény korrelál a Kekecs és mtsai [43] által végzett metaanalízis eredményével, melyből az derült ki, hogy a terápiás szuggesztiók nem csökkentették szignifikánsan a mútétek utáni gyógyszerigényt. A jelen vizsgálatban ennek három fó oka lehet. Az egyik az, hogy a beteg - fóleg az első két napon - nem igény szerint, hanem inkább protokoll alapján kapja a gyógyszert (például az 1-2. napon kivétel nélkül mindenki kap diklofenákinfúziót). A másik ok, amely elsősorban a 3-6. napon fordulhat elö, az, hogy a nővérek esetleg akkor is a betegnél hagyják a fájdalom- csillapítót, ha a beteg éppen nem kér gyógyszert. Így lehetséges, hogy időnként olyan gyógyszert jegyeztek fel beszedettként, amelyet valójában nem vett be a beteg, de az is előfordulhat, hogy ha a gyógyszer kéznél van, a beteg annak ellenére is beveszi a fájdalomcsillapítót, hogy nincs olyan mértékú fájdalma, amelyre egyébként gyógyszert venne be. Ugyanakkor az is lehetséges, hogy a mütét utáni 3-6. napon a mútét előtt és alatt alkalmazott szuggesztiók már kevésbé fejtik ki hatásukat.

Csípő- és térdprotézismütéteknél a betegek számára jellemzően a műtét napja és az azt követő nap a legnehezebb, mivel ez az az időszak, amikor a betegeknek a legnagyobb fájdalmuk van, és a legkevésbé mobilisak. Erre az időszakra vonatkozóan az intervenciós csoport betegei külön szuggesztiót kaptak a személyes beszélgetés során. A közérzetbecslő arcskála eredménye a szuggesztió hatását egyértelmúen tükrözi: míg a kontrollcsoport betegeinek közérzete romlott a mütét utáni napon, a szuggesztiós csoport betegeinek közérzete nem változott negatív irányba. A két csoport közötti szignifikáns különbség azonban a mütét utáni 6. napra eltünt, ami szintén utalhat arra, hogy az alkalmazott szuggesztiók a későbbi időpontokban már kevésbé hatnak, vagy a plafonhatás miatt a közérzet javulása már nem mérhető jól ezzel a mérőeszközzel a magasabb közérzeti régióban. A közérzetre kifejtett hatás időbeli megjelenése hasonló a Jakubovits és mtsai [28] által végzett vizsgálat eredményeihez, ugyanakkor mások nem találtak a közérzetben javulást a közvetlen posztoperatív időszakban [44]. A közérzetbecslő arcskálával kapott eredményeink kapcsán azt is meg kell jegyezni, hogy az arcskála átlagos kiindulási (mútét előtti) értéke a szuggesztiós csoportban 0,8 ponttal magasabb a kontrollcsoporthoz képest. Ez biztosan nem a szuggesztiók hatásának köszönhető, hiszen a beteg közérzetét a szuggesztiós beavatkozás előtt mértük fel. Továbbá ez a kiindulási különbség a vizsgálati eredményünket valószínúleg nem befolyásolja, hiszen a statisztikai számításnál a csoportokon belüli kiindulási értékekhez mért változásokat hasonlítottuk össze.

Vizsgálataink során a két csoport között a szövődmények, láz, hőemelkedés gyakoriságát illetően nem találtunk különbséget, Jakubovits és mtsai [28] eredményeihez hasonlóan. Ez magyarázható azzal, hogy a szövődmények gyakorisága ezen mütéteknél egyébként is relatíve alacsony, hiszen a mútéteket tervezetten, általában jó általános állapotú betegeken végezzük. A kórházban töltött napok számában sem adódott eltérés a két csoport között. A mi kutatásunkhoz hasonló vizsgálatok eredményei a kórházi tartózkodást illetően ellentmondásosak. Blankfield [45], Jakubovits [28] és van der Laan [46] nem észlelte a hospitalizáció rövidülését a perioperatív időszakban alkalmazott szuggesztiók hatására, míg Evans [47] és Bonke [48] igen. Az, hogy a mi vizsgálatunkban nem csökkent a kórházban töltött napok száma a szuggesztiós csoportban, nem feltétlenül tükrözi a betegek gyógyulását, felépülését, hanem sokkal inkább az intézeti protokoll alkalmazásának köszönhető. 


\section{Erösségek, korlátok}

Vizsgálatunk egyik erőssége, hogy a betegek azonos típusú mútéteken estek át, és bent fekvő betegként nagyjából azonos környezeti hatások érték őket. Ezen túlmenően a mútét előtti beszélgetést ugyanaz a személy vezette előre kidolgozott lépéseket követve, így az intervenció is standardizáltnak tekinthető. Tovább erősíti a konklúziók megbízhatóságát a prospektív randomizált kontrollált elrendezés, és hogy a vizsgált kimeneti változók a közérzetbecslő arcskálát leszámítva objektív paraméterek. Az alkalmazott terápiás szuggesztiók nem jelentenek különleges bánásmódot vagy többletidőt, könnyen beépíthetők az amúgy is kötelező/elvárt, mütét előtti tájékoztató beszélgetésbe.

$\mathrm{Az}$ intervenció direkt hatásának interpretációját viszont nehezíti, hogy a csoporttagság maszkolása - részben a beavatkozás természetéből adódóan - nem volt megoldható. Így elképzelhető, hogy a kórházi személyzet vagy a betegek elvárásai csoportspecifikusan befolyásolták a kimeneti változókat. Ugyanakkor ez, bár módszertani szempontból kedvezőtlen, a szuggesztív hatások szerves velejárója: alapvetően a társas támasz egy hatékony módjáról van szó, amelynél a mechanizmus része lehet, hogy nyilvánosan, mások előtt zajlik. Az adatgyújtés szintén nem volt maszkolt, így az arcskála felvételekor felmerül, hogy a szuggesztiós csoport betegei az elvárásoknak akartak megfelelni.

$\mathrm{Az}$ orvos-beteg kapcsolat erősítése céljából esetleg hasznosabb és hatékonyabb lett volna, ha az intervenciót a betegek kezelőorvosa végzi. Ugyanakkor ez az egységesség ellen hatott volna. További dilemma, hogy az elért hatás mennyire köszönhető egyszerüen csak annak, hogy a szuggesztiós csoport betegei a többletbeszélgetéssel több törődésben részesültek a kontrollcsoport betegeihez képest. Ugyanakkor úgy éreztük, hogy egy cél nélküli beszélgetés és hanganyag használata a kontrollcsoportban etikailag megkérdőjelezhető lett volna, illetve olyan kontrollcsoportot szerettünk volna, amely a leginkább fedi a valós helyzetet.

Vizsgálatunknak nem volt része sem a betegek szuggesztibilitásának, sem pszichés állapotának a felmérése, így esetlegesen előfordulhat, hogy valamelyik csoport fogékonyabb volt a szuggesztiók iránt, vagy hogy az időskorban gyakrabban előforduló depresszió vagy más fel nem tárt tényező befolyásolhatta eredményeinket. Ugyanakkor ezeket a felméréseket nem is volt célunk elvégezni, mivel általánosan, mindenkinél alkalmazható módszer kialakítására törekedtünk.

\section{Következtetés}

Vizsgálatunk alapján elmondható, hogy az ortopédiai nagymütétek előtt alkalmazott, terápiás szuggesztiókat tartalmazó személyes beszélgetés és a mütét alatt hallgatott hanganyag hatására a betegek transzfúziós igénye és a mútét alatti gyógyszerigény (fájdalomcsillapítók és ad- juváns szerek) jelentősen csökkent, és a betegek közérzete is jobban javult. A mútét utáni szövődményekben és a mútét utáni gyógyszerszedésben viszont nem találtunk szignifikáns különbséget. További vizsgálatok végzése szükséges az említett korlátozó tényezők kiküszöbölésével, elsősorban a gyógyszerigény változásának megítélésére.

Anyagi támogatás: A közlemény megírása, illetve a kapcsolódó kutatómunka anyagi támogatásban nem részesült.

Szerzői munkamegosztás: Sz. Cs., B. Á., K. Z., S. T., Cs. Z., V. K.: A hipotézisek és a vizsgálati protokoll kidolgozása. Sz. Cs., S. T., Cs. Z.: A vizsgálat lefolytatása. B. Á.: A statisztikai elemzés elkészítése. Sz. Cs., B. Á., K. Z., V. K.: A kézirat megírása. A cikk végleges változatát valamennyi szerző elolvasta és jóváhagyta.

Érdekeltségek: A szerzőknek nincsenek érdekeltségeik.

\section{Irodalom}

[1] Szendrői T. Hip arthroplasty in the 21st century. [Csípőprotézis a XXI. században.] Orvosok Lapja 2016. 05. 20. pp. 28-29. [Hungarian]

[2] Pabinger C, Geissler A. Utilization rates of hip arthroplasty in OECD countries. Osteoarthritis Cartilage 2014; 22: 734-741.

[3] Pabinger C, Lothaller H, Geissler A. Utilization rates of kneearthroplasty in OECD countries. Osteoarthritis Cartilage 2015; 23: 1664-1673.

[4] de Jonge T, Görgényi S, Szabó G, et al. Local infiltration analgesia in total joint replacement. [Helyi infiltrációs érzéstelenítés alkalmazása nagyízületi endoprotézisek beültetése során.] Orv Hetil. 2017; 158: 352-357. [Hungarian]

[5] Pinto PR, McIntyre T, Ferrero R, et al. Predictors of acute postsurgical pain and anxiety following primary total hip and knee arthroplasty. J Pain 2013; 14: 502-515.

[6] Theunissen M, Peters ML, Bruce J, et al. Preoperative anxiety and catastrophizing: a systematic review and meta-analysis of the association with chronic postsurgical pain. Clin J Pain 2012; 28 : 819-841.

[7] Capdevila X, Barthelet $Y$, Biboulet $P$, et al. Effects of perioperative analgesic technique on the surgical outcome and duration of rehabilitation after major knee surgery. Anesthesiology 1999; 91: $8-15$.

[8] Rajeev A, Tumia N, Karn K, et al. Postoperative pain relief and functional outcome following total knee arthroplasty - a prospective comparative audit of three analgesic regimes. Acta Orthop Belg. 2016; 82: 265-270.

[9] Rasouli MR, Menendez ME, Sayadipour A, et al. Direct cost and complications associated with total joint arthroplasty in patients with preoperative anxiety and depression. J Arthroplasty 2016; 31: 533-536.

[10] Ali A, Lindstrand A, Sundberg M, et al. Preoperative anxiety and depression correlate with dissatisfaction after total knee arthroplasty: a prospective longitudinal cohort study of 186 patients, with 4-year follow-up. J Arthroplasty 2017; 32: 767-770.

[11] Abbas K, Murtaza G, Umer M, et al. Complications of total hip replacement. J Coll Physicians Surg Pak. 2012; 22: 575-578.

[12] Jonas SC, Smith HK, Blair PS, et al. Factors influencing length of stay following primary total knee replacement in a UK specialist orthopaedic centre. Knee 2013; 20: 310-315. 
[13] Doering S, Katzlberger F, Rumpold G, et al. Videotape preparation of patients before hip replacement surgery reduces stress. Psychosom Med. 2000; 62: 365-373.

[14] Johansson K, Salanterä S, Katajisto J. Empowering orthopaedic patients through preadmission education: results from a clinical study. Patient Educ Couns. 2007; 66: 84-91.

[15] Seers K, Crichton N, Tutton L, et al. Effectiveness of relaxation for postoperative pain and anxiety: randomized controlled trial. J Adv Nurs. 2008; 62: 681-688.

[16] Forward JB, Greuter NE, Crisall SJ, et al. Effect of structured touch and guided imagery for pain and anxiety in elective joint replacement patients - a randomized controlled trial: M-TIJRP. Perm J. 2015; 19: 18-28.

[17] Jacobson AF, Umberger WA, Palmieri PA, et al. Guided imagery for total knee replacement: a randomized, placebo-controlled pilot study. J Altern Complement Med. 2016; 22: 563-575.

[18] Doering LV, Cross R, Vredevoe D, et al. Infection, depression, and immunity in women after coronary artery bypass: a pilot study of cognitive behavioral therapy. Altern Ther Health Med. 2007; 13: 18-21.

[19] Mauer M. Medical hypnosis and orthopedic hand surgery: pain perception, post-operative recovery, and adherence [e-book] ProQuest Information \& Learning, US, 1995. Available from: PsycINFO, Ipswich, MA [accessed: October 26, 2015].

[20] Flory N, Salazar GM, Lang EV. Hypnosis for acute distress management during medical procedures. Int J Clin Exp Hypn. 2007; 55: 303-317.

[21] Montgomery GH, David D, Winkel G, et al. The effectiveness of adjunctive hypnosis with surgical patients: a meta-analysis. Anesth Analg. 2002; 94: 1639-1645.

[22] Schnur JB, Kafer I, Marcus C, et al. Hypnosis to manage distress related to medical procedures: a meta-analysis. Contemp Hypn. 2008; 25: 114-128.

[23] Perczel K, Gál J. Hypnotherapy of atopic dermatitis in an adult. Case report. [Felnőttkori atopiás dermatitis hipnoterápiás kezelése.] Orv Hetil. 2016; 157: 111-115. [Hungarian]

[24] Tefikow S, Barth J, Maichrowitz S, et al. Efficacy of hypnosis in adults undergoing surgery or medical procedures: a meta-analysis of randomized controlled trials. Clin Psychol Rev. 2013; 33: 623-636.

[25] Kekecs Z, Jakubovits E, Varga K, et al. Effects of patient education and therapeutic suggestions on cataract surgery patients: a randomized controlled clinical trial. Patient Educ Couns. 2014; 94: 116-122.

[26] Schlanger J, Fritúz G, Varga K. Therapeutic suggestion helps to cut back on drug intake for mechanically ventilated patients in intensive care unit. Interv Med Appl Sci. 2013; 5: 145-152.

[27] Liu WH, Standen PJ, Aitkenhead AR. Therapeutic suggestions during general anaesthesia in patients undergoing hysterectomy. Br J Anaesth. 1992; 68: 277-281.

[28] Jakubovits E, Janecskó M, Varga K. The effect of pre- and intraoperative suggestions on patients' postoperative condition. [Mútét előtti-alatti szuggesztiók hatása a betegek posztoperatív állapotára.] Aneszteziol Intenzív Ter. 1998; 28: 3-9. [Hungarian]

[29] Szilágyi AK, Diószeghy Cs, Benczúr L, et al. Effectiveness of psychological support based on positive suggestion with ventilated patient. Eur J Ment Health 2007; 2: 149-170.

[30] Szilágyi AK, Diószeghy C, Fritúz G, et al. Shortening the length of stay and mechanical ventilation time by using positive suggestion via MP3 players for ventilated patients. Interv Med Appl Sci. 2014; 6: 3-15.

[31] Varga K, Diószeghy Cs. Cash in for refrigeration, or the role of suggestions in everyday medical practice. [Hütésbefizetés, avagy a szuggesztiók szerepe a mindennapi orvosi gyakorlatban.] Pólya Kiadó, Budapest, 2001. [Hungarian]

[32] Varga K. (ed.) Suggestive communication in somatic medicine. [Szuggesztív kommunikáció a szomatikus orvoslásban.] Országos Addiktológiai Intézet, Budapest, 2005. [Hungarian]

[33] Varga K, Diószeghy Cs, Fritúz G. Suggestive communication with the ventilated patient. Eur J Ment Health 2007; 2: 137147.

[34] Disbrow EA, Bennett HL, Owings JT. Effect of preoperative suggestion on postoperative gastrointestinal motility. West J Med. 1993; 158: 488-492.

[35] Szeverényi C, Csernátony Z, Balogh Á, et al. Effects of positive suggestions on the need for red blood cell transfusion in orthopedic surgery. Int J Clin Exp Hypn. 2016; 64: 404-418.

[36] PICOS model. Available from: https://researchguides.uic. edu/c.php?g=252338\&p=3954402 [accessed: July 6, 2018].

[37] Szeverényi C, Csernátony Z, Balogh Á, et al. Examples of positive suggestions given to patients undergoing orthopaedic surgeries. Interv Med Appl Sci. 2013; 5: 112-115.

[38] McGrath PA, Seifert CE, Speechley KN, et al. A new analogue scale for assessing children's pain: an initial validation study. Pain 1996; 64: 435-443.

[39] Varga K. (ed.) Beyond the words. Communication and suggestion in medical practice. [A szavakon túl. Kommunikáció és szuggesztió az orvosi gyakorlatban.] Medicina Kiadó, Budapest, 2011. [Hungarian]

[40] Varga K. Suggestive techniques connected to medical interventions. Interv Med Appl Sci. 2013; 5: 95-100.

[41] Bejenke CJ. Preparation of patients for stressful medical interventions: some very simple approaches. In: Peter B, Trenkle B, Kinzel FC, et al. (eds.) Hypnosis International Monographs No. 2: Munich lectures on hypnosis and psychotherapy. MEG-Stiftung, München, 1996; pp. 27-36.

[42] Diószeghy C, Varga K, Fejes K, et al. Use of positive suggestions in medical practice: experiences in the intensive care unit. [Pozitív szuggesztiók alkalmazása az orvosi gyakorlatban: tapasztalatok az intenzív osztályon.] Orv Hetil. 2000; 141: 1009-1013. [Hungarian]

[43] Kekecs Z, Nagy T, Varga K. The effectiveness of suggestive techniques in reducing postoperative side effects: a meta-analysis of randomized controlled trials. Anesth Analg. 2014; 119: 14071419.

[44] Nilsson U, Rawal N, Enqvist B, et al. Analgesia following music and therapeutic suggestions in the PACU in ambulatory surgery; a randomized controlled trial. Acta Anaesthesiol Scand. 2003; 47: 278-283.

[45] Blankfield RP, Zyzanski SJ, Flocke SA, et al. Taped therapeutic suggestions and taped music as adjuncts in the care of coronaryartery-bypass patients. Am J Clin Hypn. 1995; 37: 32-42.

[46] van der Laan WH, van Leeuwen BL, Sebel PS, et al. Therapeutic suggestion has not effect on postoperative morphine requirements. Anesth Analg. 1996; 82: 148-152.

[47] Evans C, Richardson PH. Improved recovery and reduced postoperative stay after therapeutic suggestions during general anaesthesia. Lancet 1988; 2: 491-493.

[48] Bonke B, Schmitz PI, Verhage F, et al. Clinical study of so-called unconscious perception during general anaesthesia. Br J Anaesth. 1986; 58: 957-964.

(Szeverényi Csenge dr., Debrecen, Nagyerdei krt. 98., 4032 e-mail: szcsenge@med.unideb.hu) 